\title{
A HYBRID MULTIPLE CRITERIA EVALUATION METHOD OF RANKING OF CULTURAL HERITAGE STRUCTURES FOR RENOVATION PROJECTS
}

\author{
Zenonas TURSKIS ${ }^{\text {a,*, Zydrune MORKUNAITE }}{ }^{\text {b }}$, Vladislavas KUTUT ${ }^{\text {b }}$ \\ ${ }^{a}$ Research Institute of Smart Building Technologies, Vilnius Gediminas Technical University, Sauletekio \\ al. 11, LT-10223 Vilnius, Lithuania \\ ${ }^{b}$ Department of Construction Technology and Management, Vilnius Gediminas Technical University, \\ Sauletekio al. 11, LT-10223 Vilnius, Lithuania
}

Received 1 June 2016; accepted 16 January 2017

\begin{abstract}
Cultural heritage item preservation, renovation and adaptation to the social needs of people, as well as their passing from generation to generation, is a problem relevant from economic, historical, archeological, religious, technological, research and other perspectives. They are typical strategic multi-criteria decision-making problems. The state institutions and the owners and managers of the heritage items invest in their preservation. In fact, every country has a great number of the registered heritage structures. To ensure their effective management and renovation, a lot of implementation projects and strategies should be developed and evaluated. This work requires large investments and time. The paper presents a hybrid model developed for ranking the heritage buildings intended for renovation according to their value. The model for problem solution based on integrated using two MCDM methods Analytic Hierarchy Process and EDAS. A set of the criteria for evaluating the projects, concerning the renovation of cultural heritage items defined.
\end{abstract}

KEYWORDS: Cultural heritage; Buildings projects; Hybrid; Multi-criteria decision-making; Evaluation; AHP; EDAS

\section{INTRODUCTION}

Cultural heritage may be considered a distinctive characteristic of any state and its citizens. The preservation of strategic heritage items is a factor, which can ensure the national security of a state. In the time of globalization, cultural heritage becomes closely associated with various economic activities, such as tourism, real estate management, education, etc. (Jureniene, Radzevicius 2014). However, cultural heritage is a system of constituent parts, which are difficult to measure and evaluate and which strongly depend on economic factors. At present, cultural heritage evaluation and preservation are aimed at determining the subjective factors, such as the value, the role and function of a heritage item rather than at searching for the objective truth. The main problem of the heritage preservation and renovation today is to determine, why and for what purposes the heritage item should be preserved. Only when

\footnotetext{
* Corresponding author. E-mail: zenonas.turskis@vgtu.lt
}

these questions are answered, the appropriate engineering solutions can be sought. At present, the main motivating factors of heritage preservation are defined as follows:

1. Preserving and/or increasing the heritage item's value for research;

2. Preserving and/or increasing the social or symbolic heritage item's value (as perceived by large groups of people);

3 . Preserving and/or increasing the sentimental, symbolic heritage item's value (as perceived by small groups of people or individuals).

Republic of Lithuania Law on Protection of Immovable Cultural Heritage (2004) defines cultural heritage property as an essential part of cultural heritage, embracing physical items of cultural value, which continue or ceased to exist. They have been created, built and preserved by the previous generations and are closely connected with some important historical events and the area of their 
location and use. The cultural heritage property includes individual items (buildings), their groups and the areas of their location.

However, under the current environmental conditions and the harmful effect of human activities, the threat to cultural heritage is increasing (Vodopivec et al. 2014). The register of the valuable items in Lithuania contains more than 24500 such items, while their number in the state list of the registered heritage items exceeds 8750 items. To preserve the cultural heritage, about 130-150 items are annually renovated. The work associated with cultural heritage items management (including research, preservation, restoration, adaptation to the current needs, etc.) is coordinated with the Cultural Heritage Department of the Ministry of Culture, as well as with municipalities and heritage item managers. The department of the cultural heritage, striving to ensure the appropriate preservation of the cultural heritage property, planned to pay special attention to the wooden architecture structures found in the ethnographic villages. Moreover, the significance level of the structure, the perspectives of its preservation, use, demonstration and visiting by the people, as well as the initiatives of its owners, should be taken into consideration. However, the costs of the heritage structure's preservation often exceed the benefits (Dutta, Husain 2009). Since renovation works are performed simultaneously in more than 130 heritage buildings per year in Lithuania, they may last for more than 36 months, depending on financing. However, a long building renovation period poses a risk to steady financing or can suspend it, leaving the work unfinished. This may happen if the cost of labour and building materials grows, the laws regulating the renovation works or taxes change or contractors and subcontractors become insolvent.

Taking these facts into consideration, the authors of the paper presented the method of more objective selection of heritage buildings, requiring financing of their renovation works, which can help to reduce the time of the work performance.

\section{A DESCRIPTION OF THE CRITERIA DEFINING THE CULTURAL HERITAGE PROPERTY, WHICH ARE USED IN MULTIPLE CRITERIA EVALUATION}

The preservation and use of cultural heritage for the current social needs, as well as its identification, evaluation, accessibility and academic research into the related problems, make an inherent part of the country's culture. On the other hand, the cultural heritage may be considered to be an economic sector, which creates the value added and should be managed so that all its valuable items would be preserved and the rights of the future generations would not be violated. Urban blight issues have transformed over time. Today, the focus is on the social context and such services as recreation and leisure (Pourahmad et al. 2015). Filip et al. (2014) emphasized that an almost exponentially increasing interest could be observed in publications analysing multi-criteria decisionmaking problems over the last decade.

There are many works, in which researchers study cultural heritage preservation problems based on using multiple criteria evaluation and decision making approaches (Zagorskas et al. 2014; Kutut et al. 2013; Turskis et al. 2013; Ksiazek et al. 2015; Siozinyte et al. 2014; Zavadskas et al. 2014). The techniques and planning methods, as well as decision-making methods, develop dynamically (Sivilevicius et al. 2008). Preservation of heritage buildings and their adaptation to the current needs of people are closely related to renovation of buildings (Ruzgys et al. 2014) and their surroundings (Turskis et al.2015; Zavadskas et al. 2015), design and management (Turskis et al. 2009), as well as refurbishment (Stankevicius et al. 2014) and the available information (Zavadskas et al. 2009a).

The authors state that, in terms of the sustainable development concept, the key criteria, on which the modern society relies, are economic, environmental and social. Other criteria often mentioned by various researchers refer to historic, cultural and aesthetic aspects of activities or interest. The criteria, describing risks and state of preservation of a building, are also referred to the key criteria. Moreover, Vodopivec et al. (2014) used the key criteria and subcriteria for arranging the architectural heritage buildings in the priority order for renovation. Thus, the authors attributed three subcriteria to each of the eight key criteria (referring to social, aesthetic, economic, culturalsymbolic, risk, environmental, preservation state of a building and historical areas).

Tupenaitè et al. (2010) offered to use the criteria for evaluating the buildings' renovation alternatives, taking into consideration macro-, mezo- and micro-levels, because the research has shown that most of the authors give the priority to renovation processes, decision making and the sustainable renovation methods of buildings mostly at the macroand (sometimes) the micro-level. However, a model aimed at analysing the renovation of buildings and 
their territory, which would take into account the interested states and macro- and micro- level criteria, as well as their effect on a building and the environment, has not been developed yet. The discovery of the existence of social preferences, perceived as positive and/or negative predispositions towards some particular social and economic conditions considerably complicated the theory of economic rationality (Morselli 2015). Problems arising in construction projects are complicated and usually involve great uncertainties and subjectivities. An appropriate mechanism for supporting design management practices at an early stage of the project is crucial in terms of adding the value over the scope, time and total investment strategic decisions (Saparauskas et al. 2011).

Compared to many other industries, the construction industry is subject to more risks due to the unique features of construction activities, such as long duration of construction projects, characterized by complicated processes, abominable environment, financial intensity, and dynamic organizational structures (Lazauskas et al. 2015). The project preparation and realization processes, based on theoretical and empirical studies and the creation of goods, services and technologies, are the most important human activities (Peldschus et al. 2010). Besides, the multi-criteria evaluation of buildings before and after refurbishment and/ or renovation and the refurbishment efficiency is required (Zavadskas et al. 2009b).

The heritage buildings can be divided into four groups, depending on their historical value, architectural value and function as follows:

- The buildings of group 1 have the unalterable structure and facade and the acceptable function;

- The buildings of group $2 \mathrm{~A}$ allow only for the modification of the exterior and some functional changes;

- The buildings of group $2 \mathrm{~B}$ allow for structural changes and extension, which may be followed by the exterior and functional changes. These alterations should be in harmony with the building's surroundings.

- The buildings of group 3 allow for all kinds of alterations (Dutta, Husain 2009).

Dutta and Husain (2009) analysed the problems of preserving the heritage items having a cultural value, taking into consideration the above four groups of cultural heritage items and applying multiple criteria evaluation methods based on the criteria associated with historical, architectural, social-cultural spheres, as well as acces- sibility, integrity, public opinion, local responses and practicality. Changes in the macro- and microenvironment, as well as growing awareness, customer requirements and increasing environmental restrictions gave rise to the need for changing the current socio-economic development to a more sustainable process (Urbaniec 2015).

Cultural heritage can be compared with an industry, which controls and plans the operations aimed at preserving the heritage items. Cultural heritage can attract tourists, who are interested in seeing various famous heritage items. Ferretti et al. (2014) have offered to evaluate heritage items based on using multiple criteria evaluation approaches, such as ARAS and AHP and taking into account the interests of tourists. The research is aimed at determining the most suitable historical building, which would be reconstructed for tourists. To achieve this, the conditions (e.g. the quality of the adjacent buildings and the environment, the accessibility of a park and airports), as well as the economic activities, flexibility (the possibility of retaining the initial function and the authenticity of a building), the accessibility and conservation (preservation) level, have been considered. Kutut et al. (2014) have stated that the effectiveness of conservation of buildings depends on the possibility of making historical places habitable in the process of future urban development.

\section{DETERMINING THE EVALUATION CRITERIA USED IN THE ANALYSIS OF THE CULTURAL HERITAGE PROPERTY}

\subsection{Determining the evaluation criteria of the cultural heritage structures intended for renovation}

The term 'heritage' embraces the monuments, buildings and their groups, having a historical, aesthetic, archeological, research, ethnological and anthropological value (Dutta, Husain 2009). Numerous researchers, trying to help preserve cultural heritage items, studied them from economic, social, political, historical and cultural aspects for determining their value.

Thus, Ferretti et al. (2014) have stated that cultural heritage is a multifaceted phenomenon. However, it most strongly depends on the economic development of the public sector. According to Vodopivec et al. (2014), the value of economic heritage property is perceived as a quantitative criterion expressed in terms of cost. However, the expression of this criterion is also associated with 
the indirect economic effect, e.g. the increased flow of tourists. At the same time, the considered criterion can be referred to the social value. Thus, Bielinskas et al. (2015) have described the economic value as the ratio of the property cost on the territory of the municipality, where it is located, and its cost on the territory of the neighbouring municipality. The property value, as well as public and private sectors' investments and a mismatch between the labour force and vacancies have been also described in this way. Tupenaite et al. (2010) considered the economic value in terms of the economic project implementation, embracing meeting the budget, contribution to project implementation, profit generation and the value added, as well as economic efficiency of the project, the financing of project implementation, etc. The necessity for investing in cultural heritage building repair or renovation can be referred to the economic value of the cultural heritage item (Kutut et al. 2014).

Another widely discussed cultural heritage value is a social value. It is defined in terms of education, research and management (Vodopivec et al. 2014). A social value can be considered, dealing with the number of the unemployed immigrants, crime level, etc. (Bielinskas et al. 2015). Tupènaite et al. (2010) have referred a social value to the macro-level. Moreover, the economic behaviour of humans is socially affected (Ashworth 2010). Besides, the laws, directives and regulations, concerning cultural heritage are associated with the political value (Ashworth 2010). When cultural heritage is considered, historical and cultural values are usually mentioned. A historical value is defined in spiritual-religious and secular terms and in the sense of novelty, while a cultural value is described in archeological and technological terms (Vodopivec et al. 2014).

The authors, studying cultural heritage, also take into account the environmental, aesthetic, risk and authenticity factors (Vodopivec et al. 2014), as well as scientific, technical (Tupenaitè et al. 2010), internal criteria (the function and age of a building) (Clark, Maeer 2008), recoupment, visual effect (Pankhurst, Harris 2013), accessibility, integrity, practicalness (Dutta, Husain 2009), the situation quality, flexibility, and the conservation level (Ferretti et al. 2014).

In selecting the wooden architecture structures for renovation, the Cultural Heritage Department primarily emphasized the importance of the criterion referring to lightning rod installation. Then, the attention was paid to such criteria as the significance level of a building, its valuable features, authenticity, the perspectives of preserving a building in the desired condition, as well as the

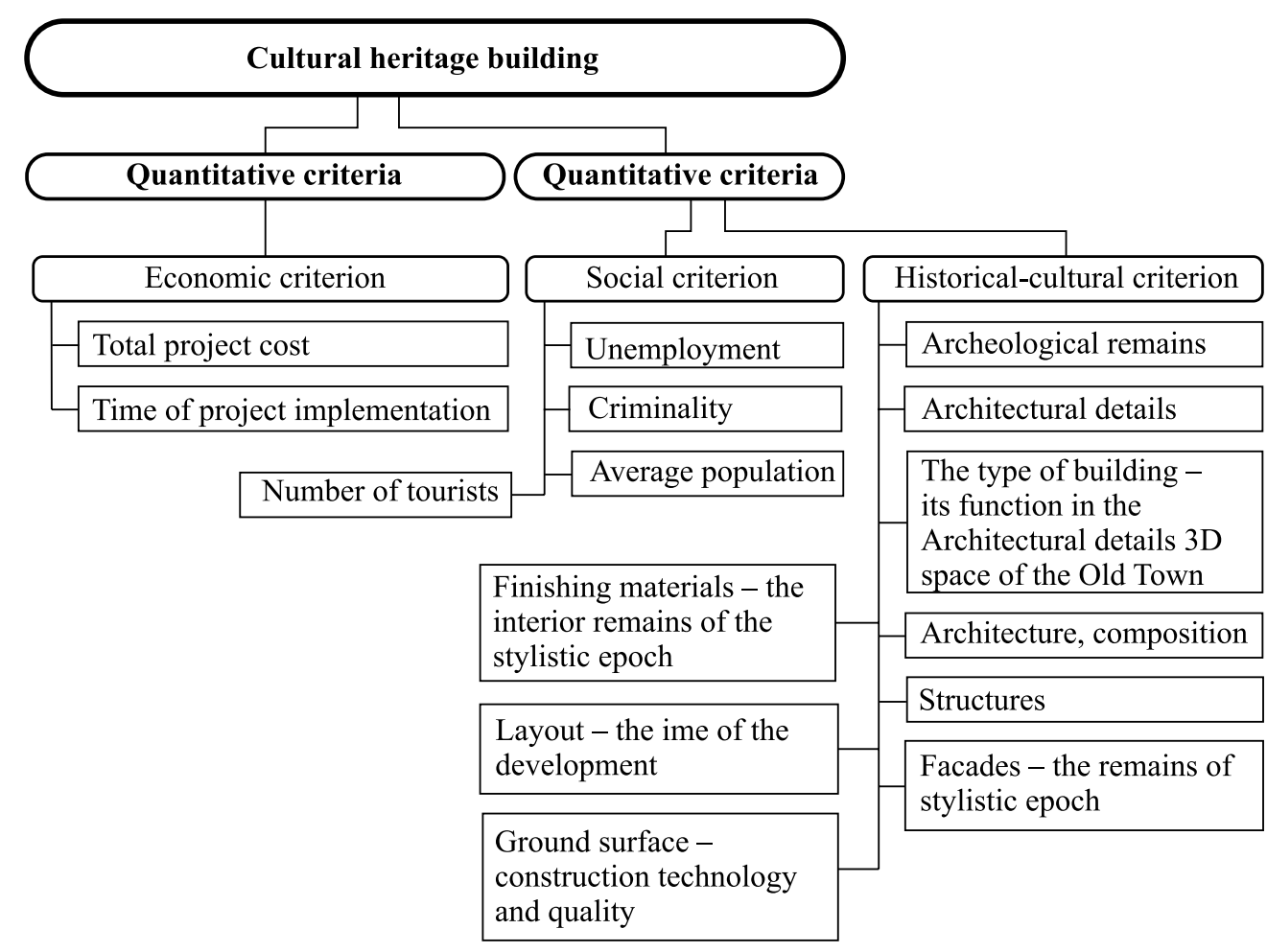

Fig. 1. Quantitative and qualitative criteria and subcriteria used in describing cultural heritage buildings 
possibilities of its proper use, demonstration to tourists and other people and the initiatives of the managers of a building and its current state.

The present paper considers the problem of choosing the cultural heritage buildings for renovation based on using quantitative and qualitative criteria (Fig. 1) and subcriteria. The main quantitative criterion is an economic criterion $\left(\mathrm{x}_{1}\right)$ of the considered building, which has some subcriteria, such as the total cost of the project $\left(\mathrm{x}_{11}\right)$ and time of project implementation $\left(\mathrm{x}_{12}\right)$. The qualitative criterion includes the social and historical-cultural criteria and historical-cultural criteria, $\left(\mathrm{x}_{2}\right)$ and $\left(\mathrm{x}_{3}\right)$, respectively. The historical-cultural criterion is considered, taking into account subcriteria, describing various features of a building, such as its valuable qualities $\left(\mathrm{x}_{21}\right)$, architecture $\left(\mathrm{x}_{22}\right)$, architectural features $\left(\mathrm{x}_{23}\right)$, the layout $\left(\mathrm{x}_{24}\right)$, facades $\left(\mathrm{x}_{25}\right)$, structures $\left(\mathrm{x}_{26}\right)$, finishing materials $\left(\mathrm{x}_{27}\right)$ and the ground surface $\left(\mathrm{x}_{28}\right)$. The social criterion embraces such subcriteria as the unemployment level $\left(\mathrm{x}_{31}\right)$, the registered crimes $\left(\mathrm{x}_{32}\right)$, the average annual population $\left(\mathrm{x}_{33}\right)$ and the number of the local tourists $\left(\mathrm{x}_{34}\right)$. Social subcriteria are considered, depending on districts (e.g. Panevėžys, Marijampolé, Vilnius or Kaunas districts), where the considered cultural heritage buildings are located.

\subsection{A description of the evaluated cultural heritage buildings}

To stimulate the performance of the renovation works of cultural heritage buildings and their financing in Lithuania, the buildings of the historical and cultural value of this country have been considered in the paper. Five various cultural heritage buildings, presented to the Cultural Heritage Department as the renovation projects by their managers, have been chosen for the analysis. The aim of the managers was to get the funding for the renovation works required for the cultural heritage buildings.

The renovation works to be performed in Bobriškis Church of Old Believers (Kultūros paveldo departamentas ... 2016a). In the 19th century, Bobriškis had become a religious centre of the North-Eastern Lithuania, while the role of the Bobriškis Church for the Old Believer community had grown immensely. The architecture of the Church is characteristic of the wooden churches in the Northern Russia. However, it also has some features of traditional Lithuanian folk architecture. In 2007, Bobriškis Old Believer Church was included in the Register of Cultural Heritage
Buildings (Fig. 2). The planned renovation works are aimed at preserving and exposing the most valuable features of the church building, because it is the oldest wooden church of Old Believers in Lithuania.

The renovation works to be performed in Vilnius synagogue, 6, Gèliu str. (Kultūros paveldo departamentas ... 2016b). The synagogue was built at the beginning of the 19th century on the site of the former wooden houses belonging to the merchant Zavelij Peisachovichius. In the second half of the 19th century, it had been reconstructed many times and extended. The church was open until 1940. After World War II, storehouses and flats were made in its building, while since the end of the 20th century, the building had been neglected. Now, Vilnius synagogue is included in the Register of Cultural Heritage Buildings (Fig. 3). The renovation works are aimed at preserving the authenticity and valuable features of Vilnius synagogue, as well as making them more prominent.

The renovation works on the roof of Raseiniai Church of Assumption of the Blessed Virgin Mary (Kultūros paveldo departamentas ... 2016c). This is the first church built in 1416-1421, at the time of Christenization of Samogitians. In 1663, the church

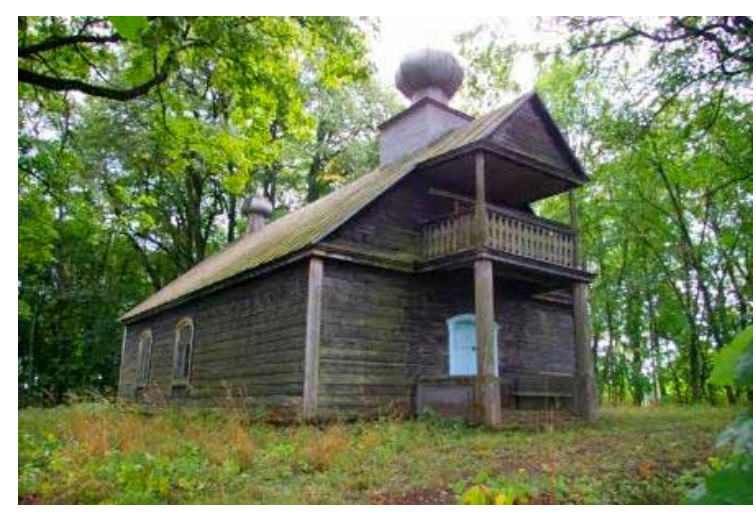

Fig. 2. Bobriškis Church of Old Believers

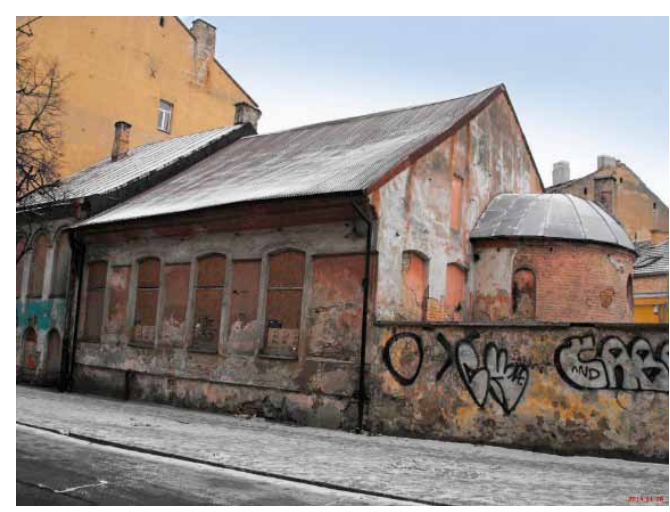

Fig. 3. Vilnius synagogue, Gèlių str. 
was reconstructed and the Dominican monastery was built, which was extended in 1682 . This church is considered to be built in one of the oldest centres of Žemaitija's rural districts. The building is a part of the church and the former Dominican monastery complex. In 1992, the church was included in the Register of Cultural Heritage Buildings (Fig. 4). The renovation works of the roof are aimed at preserving the valuable features of this heritage building and completing all the works of church renovation.

The renovation works of Zypliai manor Craftsmen Home (Kultūros paveldo departamentas ... 2016d). Zypliai manor Craftsmen Home belongs to Zypliu manor complex. According to the historical and iconographical data on the manor, it was built as a house of the manager in charge of the premises. In the first half of the 20th century, it was repaired and made the craftsmen home. In 1999, Zypliai manor Craftsmen Home was included in the Register of Cultural Heritage Buildings (Fig. 5). The planned renovation project solutions are aimed at preserving the valuable features of the building and showing them to the public.

The conservation and renovation of St. Stephen Church facades (Kultūros paveldo departamentas ... 2016e). The St. Stephen Church is a rare Mannerist architecture monument in Lithuania, which is also important for the history of its culture as

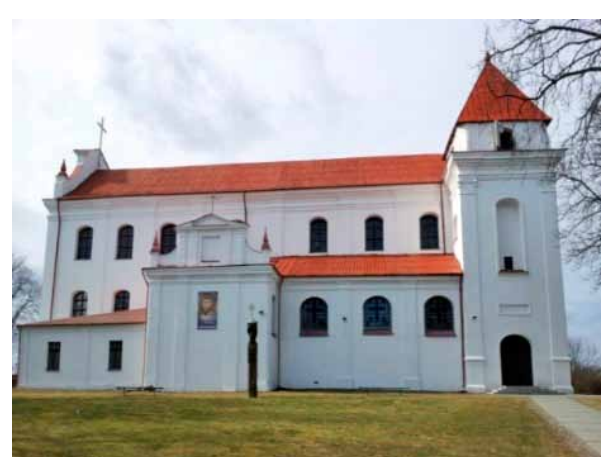

Fig. 4. Raseiniai Assumption of the Blessed Virgin Mary Church

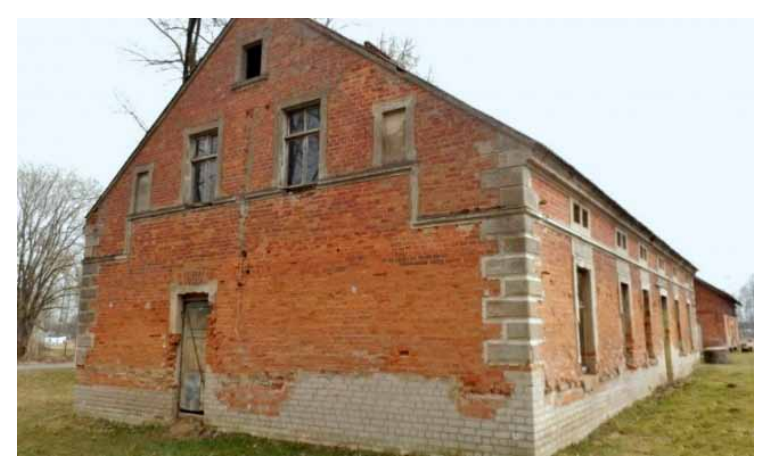

Fig. 5. Zypliai manor Craftsmen Home

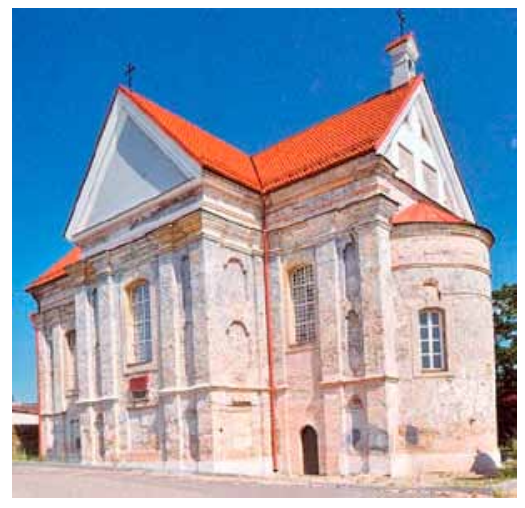

Fig 6. St. Stephen Church

the former centre of the monks, St. Roch's followers. The church was built in 1600 on the initiative of Simonas Visockis, a Jesuit priest, in the Southern part of the town near the walls of the cemeteries, which appeared in the time of the plague. A famous architect Laurynas Gucevičius was buried there in the 18th century, which is witnessed by the plate on the external wall of the church. In 1717, St. Roch chapel was attached to the church building. In 1863-1914, the church buildings were used as the town prison. In 1944, the building of the church was connected with a factory and used as a warehouse for storing various materials. The church is a building constructed in the late Renaissance style. It was reconstructed in the period of classicism. In 1992, the church was included in the Register of Cultural Heritage Buildings (Fig. 6). It is planned to preserve the valuable features of the church by renovating it and its territory, to return it to the believers and adapt to the social needs of the community.

\subsection{Determining the criteria weights and selecting the cultural heritage buildings for renovation by applying the Analytic Hierarchy Process (AHP) approach}

A fundamental problem of the decision theory is associated with the determination of weights for a set of criteria according to their importance (Saaty 1980). A variety of methods have been proposed for eliciting the criteria weights. The "best" method for determining weights can hardly be found. The review of the past works has shown that the Analytic Hierarchy Process (AHP) seems to be the MCDM method commonly used in solving civil engineering decision problems. This method allows for hierarchical structuring of a complicated problem, as well as comparing and quantitatively evaluating the available alternative solutions. It also allows for determining the criteria weights (significances) at a particular hierarchical level. 
Table 1. The initial data used for pairwise comparison

\begin{tabular}{|c|c|c|c|c|c|c|c|c|}
\hline \multicolumn{9}{|c|}{ Saaty's classical nine-point scale of relative importance } \\
\hline & $\begin{array}{l}\text { Diagonal } \\
\text { elements } \\
i=j\end{array}$ & $\begin{array}{l}C_{i} \text { and } C_{j} \\
\text { are equally } \\
\text { important }\end{array}$ & $\begin{array}{l}C_{i} \text { is weakly } \\
\text { more } \\
\text { important } \\
\text { than } C_{j}\end{array}$ & $\begin{array}{l}C_{i} \text { is strongly } \\
\text { more } \\
\text { important } \\
\text { than }\end{array}$ & $\begin{array}{l}C_{i} \text { is } \\
\text { demonstratively } \\
\text { more important } \\
\text { than } C_{j}\end{array}$ & $\begin{array}{l}C_{i} \text { is abso- } \\
\text { lutely more } \\
\text { important } \\
\text { than } C_{j}\end{array}$ & $\begin{array}{l}\text { Compromise } \\
\text { between two } \\
\text { judgments }\end{array}$ & $\begin{array}{l}\text { If element } C_{j} \\
\text { dominates } \\
\text { element } C_{j}\end{array}$ \\
\hline$a_{i j}$ & 1 & 1 & 3 & 5 & 7 & 9 & $2,4,6,8$ & $a_{i j}=1 / a_{i j}$ \\
\hline \multicolumn{9}{|c|}{ Random Consistency Indices (IR) for a number of various criteria $(n)$. } \\
\hline$n$ & 1 & 2 & 3 & 4 & 5 & 6 & 7 & 8 \\
\hline$R I$ & 0 & 0 & 0.58 & 0.9 & 1.12 & 1.24 & 1.32 & 1.41 \\
\hline
\end{tabular}

The analysis of a decision making problem by the AHP method starts with the generation of a hierarchical structure, which consists of the aim, alternatives, criteria, sub-criteria and other factors, influencing the final choice. Applying this method, the needs of the interested parties (i.e. managers, state institutions, clients, investors, community members, etc.) should be taken into consideration (Kutut et al. 2014). The representatives of all these groups of people evaluate the considered criteria against the scale suggested by Saaty.

Saaty recommends a nine- level dominance scale, which he described based on the Miller's (Miller 1956) magical number seven plus two number (Table 1) (Saaty 1980). The amount of $n(n-1) / 2$ judgments is required for developing the $n \times n$ judgment matrix, since reciprocals are automatically assigned in each pairwise comparison procedure. Pairwise comparison is based on the weighting principle, when one criterion is more significant than the other. The criteria and sub-criteria are compared within their groups.

The AHP method is a stepwise procedure:

Step 1. When the representative of an interested party has finished pairwise comparison of criteria, write down the results in the pairwise comparison matrix:

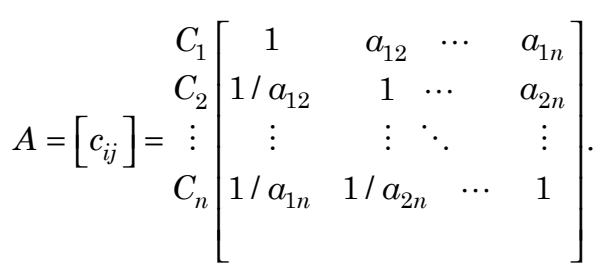

Step 2. Normalize the pairwise comparison matrix as follows:

$$
\bar{A}=\left[\bar{c}_{i j}\right]=\left[\begin{array}{cc}
c_{11} / \sum_{i=1}^{n} c_{i 1} & c_{12} / \sum_{i=1}^{n} c_{i 2} \cdots c_{1 n} / \sum_{i=1}^{n} c_{i n} \\
c_{21} / \sum_{i=1}^{n} c_{i 1} & c_{22} / \sum_{i=1}^{n} c_{i 2} \cdots c_{2 n} / \sum_{i=1}^{n} c_{i n} \\
\vdots & \vdots \\
c_{n 1} / \sum_{i=1}^{n} c_{i 1} & c_{n 2} / \sum_{i=1}^{n} c_{i 2} \cdots c_{n n} / \sum_{i=1}^{n} c_{i n}
\end{array}\right] .
$$

After normalizing, the criteria weights (significance values), which, primarily, were expressed by measuring units, have become the dimensionless values. Then, the direction of evaluation $(\min / \max )$ was determined. At this stage, the values of criteria and subcriteria weights were determined in the maximization or minimization direction (Table 3).

Step 3. Compute the criteria weights:

$W=\left[\begin{array}{c}w_{1} \\ w_{2} \\ \vdots \\ w_{n}\end{array}\right]=\left[\begin{array}{l}w_{1}=\left(\prod_{j=1}^{n} \bar{c}_{1 j}\right)^{1 / n} / \sum_{i=1}^{n}\left(\prod_{j=1}^{n} \bar{c}_{i j}\right)^{1 / n} \\ w_{2}=\left(\prod_{j=1}^{n} \bar{c}_{1 j}\right)^{1 / n} / \sum_{i=1}^{n}\left(\prod_{j=1}^{n} \bar{c}_{i j}\right)^{1 / n} \\ w_{n}=\left(\prod_{j=1}^{n} \bar{c}_{1 j}\right)^{1 / n} / \sum_{i=1}^{n}\left(\prod_{j=1}^{n} \bar{c}_{i j}\right)^{1 / n}\end{array}\right]$

Step 4. Determine the largest eigenvalue:

$$
\lambda_{\text {max }}=\sum_{j=1}^{n} c_{i j} w_{j}
$$

Step 5. Determine the Consistency Index (CI):

$$
C I=\frac{\lambda_{\max }-1}{n-1}
$$

Step 6. Determine the Consistency Ratio $(C R)$ :

$$
C R=\frac{C I}{R I},
$$

where: $R I$ (Table 1 ) represents the average consistency index over numerous random elements of the same order reciprocal matrices.

Step 7. Ensure that the pairwise comparison matrix is consistent. The matrix is consistent, when, based on the minimal number of its elements, the remaining elements can be obtained. The required condition for achieving a consistent matrix is the transitivity of the significance of its elements. If $\mathrm{CR} \leq 0.1$, it indicates that the matrix reached consistency. Otherwise, go to the first step. 
The experts' team formed to solve this problem. Experts'role in this study was to decide on a set of criteria that should be relevant for application. Fifteen experts are experienced and knowledgeable people from Department of Culture Heritage under the Ministry of Culture, owners of Culture heritage buildings, clients and people from academic institutions. Experts were required to have knowledge and experience in field of culture heritage and its management. During the evaluation process, the main criteria for selection was that candidates had to have more than seven years of experience in culture heritage field.

To select the cultural heritage buildings for renovation, 5 alternatives have been considered. Each alternative with the provided criteria and the calculated values is described in Table 2 . These values were obtained from various sources: from the projects provided by the managers of the building, from the register of the Cultural Heritage Department of the Ministry of Culture and from the site of the Statistics Department of Lithuania.

The next stage involves using the method of Evaluation based on Distance from the Average Solution (EDAS).
Ghorabaee et al. (2015) proposed a new multicriteria decision-making method called 'Evaluation based on the Distance from the Average Solution' (EDAS). Later, this method extended to reflect fuzzy environment (Ghorabaee et al. 2016).

The EDAS method can be used, when the problem under consideration is described by some conflicting criteria. The steps for using the EDAS method are as follows:

Step 1. Select the most important criteria describing the alternatives.

Step 2. Represent the problem as the decisionmaking matrix $X$ of preferences for $m$ reasonable alternatives $A_{i}$ (rows) rated on $n$ criteria (columns):

$$
X=\left[x_{i j}\right]_{m \times n}=\left[\begin{array}{cccc}
x_{11} & x_{12} & \cdots & x_{1 n} \\
x_{21} & x_{22} & \cdots & x_{2 n} \\
\vdots & \vdots & \ddots & \vdots \\
x_{m 1} & x_{m 2} & \cdots & x_{m n} \\
& & &
\end{array}\right] \text {, }
$$

where: $x_{i j}$ is the value representing the performance value of the $\underline{i}-t h$ alternative in terms of the j-th criterion.

Table 2. The alternatives and the criteria used

\begin{tabular}{|c|c|c|c|c|c|c|c|}
\hline \multirow[t]{2}{*}{ Criteria } & \multicolumn{7}{|c|}{ Alternatives } \\
\hline & & $\begin{array}{l}\text { Evalu- } \\
\text { ation of } \\
\text { criteria, } \\
\min / \max \end{array}$ & $\begin{array}{l}\text { Reno- } \\
\text { vation } \\
\text { work of } \\
\text { Bobriškis } \\
\text { Church of } \\
\text { Old Believ- } \\
\text { ers }\end{array}$ & $\begin{array}{l}\text { Renova- } \\
\text { tion work } \\
\text { of Vilnius } \\
\text { synagogue, } \\
\text { Gèlių str. } \\
6\end{array}$ & $\begin{array}{l}\text { Roof renova- } \\
\text { tion work of } \\
\text { Raseiniai As- } \\
\text { sumption of } \\
\text { the Blessed } \\
\text { Virgin Mary } \\
\text { Church }\end{array}$ & $\begin{array}{l}\text { Renova- } \\
\text { tion and } \\
\text { repair of } \\
\text { Zypliai } \\
\text { manor } \\
\text { Craftsmen } \\
\text { Home }\end{array}$ & $\begin{array}{l}\text { Conserva- } \\
\text { tion and } \\
\text { renova- } \\
\text { tion of St. } \\
\text { Stephen } \\
\text { Church } \\
\text { facade }\end{array}$ \\
\hline & & & $\mathrm{A}_{1}$ & $\mathrm{~A}_{2}$ & $\mathrm{~A}_{3}$ & $\mathrm{~A}_{4}$ & $\mathrm{~A}_{5}$ \\
\hline Economic criteria & $\mathrm{x}_{1}$ & $\min$ & & & & & \\
\hline Total project cost (thousand EUR) & $\mathrm{x}_{11}$ & $\min$ & 264.809 & 552.18 & 246.3 & 473.69 & 279.714 \\
\hline Project implementation time (months) & $\mathrm{x}_{12}$ & $\min$ & 36 & 60 & 24 & 60 & 48 \\
\hline $\begin{array}{l}\text { Historical -cultural criteria (valuable } \\
\text { features) }\end{array}$ & $\mathrm{x}_{2}$ & $\max$ & & & & & \\
\hline Type of valuable features & $\mathrm{x}_{21}$ & $\max$ & 2 & 2 & 4 & 1 & 6 \\
\hline Architecture & $\mathrm{x}_{22}$ & $\max$ & 6 & 8 & 11 & 5 & 17 \\
\hline Architectural details & $\mathrm{x}_{23}$ & $\max$ & 0 & 0 & 24 & 0 & 20 \\
\hline Layout & $\mathrm{x}_{24}$ & $\max$ & 3 & 10 & 14 & 11 & 9 \\
\hline Facades & $\mathrm{x}_{25}$ & $\max$ & 15 & 7 & 16 & 15 & 9 \\
\hline Structures & $\mathrm{x}_{26}$ & $\max$ & 7 & 6 & 16 & 10 & 23 \\
\hline Finishing materials & $\mathrm{x}_{27}$ & $\max$ & 2 & 0 & 1 & 3 & 0 \\
\hline Ground surface & $\mathrm{x}_{28}$ & $\max$ & 1 & 0 & 0 & 0 & 2 \\
\hline $\begin{array}{l}\text { Social criteria } \\
\text { (according to particular districts) }\end{array}$ & $\mathrm{x}_{3}$ & $\begin{array}{l}\operatorname{Min} / \\
\max \end{array}$ & & & & & \\
\hline Unemployment level, \% & $\mathrm{x}_{31}$ & $\min$ & 10.2 & 7.3 & 7.6 & 10.3 & 7.3 \\
\hline Crimes, units & $\mathrm{x}_{32}$ & $\min$ & 5820 & 22983 & 15260 & 3526 & 22983 \\
\hline Average annual population, persons & $\mathrm{x}_{33}$ & $\max$ & 233228 & 806333 & 580134 & 150459 & 806333 \\
\hline Number of tourists, thousand persons & $\mathrm{x}_{34}$ & $\max$ & 5.7 & 48.9 & 44.9 & 8.1 & 48.9 \\
\hline
\end{tabular}


Table 3. Initial data

\begin{tabular}{|c|c|c|c|c|c|c|c|c|c|}
\hline \multirow{2}{*}{$\begin{array}{l}\text { Criteria and } \\
\text { subcriteria }\end{array}$} & \multirow[t]{2}{*}{ Optimal } & \multirow{2}{*}{$\begin{array}{l}\text { Weights } \\
\text { (based on } \\
\text { AHP) }\end{array}$} & \multirow[t]{2}{*}{$w[j]$} & \multicolumn{6}{|c|}{ Alternatives } \\
\hline & & & & $A_{1}$ & $A_{2}$ & $A_{3}$ & $A_{4}$ & $A_{5}$ & $A_{\mathrm{a}}$ \\
\hline $\begin{array}{l}x_{1} \\
\end{array}$ & $\min$ & 0.709 & $x_{a \mathrm{j}}$ & & & & & & \\
\hline$x_{11}$ & $\min$ & 0.167 & 0.118 & 264.809 & 552.18 & 246.3 & 473.69 & 279.714 & 363.3 \\
\hline$x_{12}$ & $\min$ & 0.833 & 0.591 & 36 & 60 & 24 & 60 & 48 & 45.6 \\
\hline$x_{2}$ & $\max$ & 0.167 & & & & & & & \\
\hline$x_{21}$ & $\max$ & 0.076 & 0.013 & 2 & 2 & 4 & 1 & 6 & 3.0 \\
\hline$x_{22}$ & $\max$ & 0.321 & 0.054 & 6 & 8 & 11 & 5 & 17 & 9.4 \\
\hline$x_{2}$ & $\max$ & 0.167 & & & & & & & \\
\hline$x_{23}$ & $\max$ & 0.167 & 0.028 & 0 & 0 & 24 & 0 & 20 & 8.8 \\
\hline$x_{24}$ & $\max$ & 0.024 & 0.004 & 3 & 10 & 14 & 11 & 9 & 9.4 \\
\hline$x_{25}$ & $\max$ & 0.242 & 0.040 & 15 & 7 & 16 & 15 & 9 & 12.4 \\
\hline$x_{26}$ & $\max$ & 0.081 & 0.014 & 7 & 6 & 16 & 10 & 23 & 12.4 \\
\hline$x_{27}$ & $\max$ & 0.076 & 0.013 & 2 & 0 & 1 & 3 & 0 & 1.2 \\
\hline$x_{28}$ & $\max$ & 0.013 & 0.002 & 1 & 0 & 0 & 0 & 2 & 0.6 \\
\hline$x_{3}$ & $\operatorname{Min} / \max$ & 0.061 & & & & & & & \\
\hline$x_{31}$ & $\min$ & 0.065 & 0.004 & 10.2 & 7.3 & 7.6 & 10.3 & 7.3 & 8.5 \\
\hline$x_{32}$ & $\min$ & 0.129 & 0.008 & 5820 & 22983 & 15260 & 3526 & 22983 & 14114.4 \\
\hline$x_{33}$ & $\max$ & 0.205 & 0.013 & 233.228 & 806.333 & 580.134 & 150.459 & 806.333 & 515.3 \\
\hline$x_{34}$ & $\max$ & 0.601 & 0.037 & 5.7 & 48.9 & 44.9 & 8.1 & 48.9 & 31.3 \\
\hline
\end{tabular}

Step 3. Determine the average value $x_{a j}$ to all criteria:

$$
x_{a j}=\frac{\sum_{i=1}^{m} x_{i j}}{m} .
$$

Step 4. Construct the average $A_{a}$ solution based on the average values of all criteria $x_{a j}$ :

$$
A_{a}=\left[x_{a j}\right]=\left[x_{a 1}, x_{a 2}, \cdots, x_{a n}\right] \text {. }
$$

Step 5. Construct the matrix $D$ of positive, $p_{i j}$, and negative, $r_{i j}$, distances from the average $A_{a}$ solution (from the average values $x_{a j}$ ) for all $n$ criteria (Table 4):

$$
D=\left[p_{i j} ; r_{i j}\right]=\left[\begin{array}{cllc}
p_{11} ; r_{11} & p_{12} ; r_{12} & \cdots & p_{1 n} ; r_{1 n} \\
p_{21} ; r_{21} & p_{22} ; r_{22} & \cdots & p_{2 n} ; r_{2 n} \\
\vdots & \vdots & \ddots & \vdots \\
p_{m 1} ; r_{m 1} & p_{m 2} ; r_{m 2} & \cdots & p_{m n} ; r_{m n}
\end{array}\right] .
$$

For beneficial criteria, the values $p_{i j}$ and $r_{i j}$ calculated as follows:

$$
\begin{aligned}
& p_{i j}=\frac{x_{i j}-x_{a j}}{x_{a j}}, \\
& r_{i j}=\frac{x_{a j}-x_{i j}}{x_{a j}} .
\end{aligned}
$$

For non-beneficial criteria, the values $p_{i j}$ and $r_{i j}$ calculated as follows:

$$
\begin{aligned}
& p_{i j}=\frac{x_{a j}-x_{i j}}{x_{a j}}, \\
& r_{i j}=\frac{x_{i j}-x_{a j}}{x_{a j}} .
\end{aligned}
$$

Step 6. Determine the weighted sum of positive $S_{i p}$ and negative $S_{i r}$ distances from the average $A_{a}$ solution for all alternatives $A_{i}$ (from the average values $x_{a j}$ ) for all $n$ criteria:

$$
\begin{aligned}
& S_{i p}=\sum_{j=1}^{n} w_{j} p_{i j}, \text { and } \\
& S_{i r}=\sum_{j=1}^{n} w_{j} r_{i j},
\end{aligned}
$$

where: $w_{j}$ is the weight of $j$-th criterion.

Step 7. Normalise the values of $S_{i p}$ and $S_{i r}$ for all alternatives as follows:

$$
\begin{aligned}
& P_{i}=\frac{S_{i p}}{\max _{i} S_{i p}}, \\
& R_{i}=1-\frac{S_{i r}}{\max _{i} S_{i r}} .
\end{aligned}
$$


Table 4. Matrix D of positive and negative distances

\begin{tabular}{|c|c|c|c|c|c|c|}
\hline & & Alterna & ives & & & \\
\hline & & $A_{1}$ & $A_{2}$ & $A_{3}$ & $A_{4}$ & $A_{5}$ \\
\hline$x_{1}$ & & & & & & \\
\hline$x_{11}$ & $p_{11}$ & 0.271 & -0.520 & 0.322 & -0.304 & 0.230 \\
\hline & $r_{11}$ & -0.271 & 0.520 & -0.322 & 0.304 & -0.230 \\
\hline$x_{12}$ & $p_{12}$ & 0.211 & -0.316 & 0.474 & -0.316 & -0.053 \\
\hline & $r_{12}$ & -0.211 & 0.316 & -0.474 & 0.316 & 0.053 \\
\hline$x_{2}$ & & & & & & \\
\hline$x_{21}$ & $p_{21}$ & -0.333 & -0.333 & 0.333 & -0.667 & 1.000 \\
\hline & $r_{21}$ & 0.333 & 0.333 & -0.333 & 0.667 & -1.000 \\
\hline$x_{22}$ & $p_{22}$ & -0.362 & -0.149 & 0.170 & -0.468 & 0.809 \\
\hline & $r_{22}$ & 0.362 & 0.149 & -0.170 & 0.468 & -0.809 \\
\hline$x_{23}$ & $p_{23}$ & -1.000 & -1.000 & 1.727 & -1.000 & 1.273 \\
\hline & $r_{23}$ & 1.000 & 1.000 & -1.727 & 1.000 & -1.273 \\
\hline$x_{24}$ & $p_{24}$ & -0.681 & 0.064 & 0.489 & 0.170 & -0.043 \\
\hline & $r_{24}$ & 0.681 & -0.064 & -0.489 & -0.170 & 0.043 \\
\hline$x_{25}$ & $p_{25}$ & 0.210 & -0.435 & 0.290 & 0.210 & -0.274 \\
\hline & $r_{25}$ & 0.681 & -0.064 & -0.489 & -0.170 & 0.043 \\
\hline$x_{26}$ & $p_{26}$ & -0.435 & -0.516 & 0.290 & -0.194 & 0.855 \\
\hline & $r_{26}$ & -0.210 & 0.435 & -0.290 & -0.210 & 0.274 \\
\hline$x_{27}$ & $p_{27}$ & 0.667 & -1.000 & -0.167 & 1.500 & -1.000 \\
\hline & $r_{27}$ & 0.435 & 0.516 & -0.290 & 0.194 & -0.855 \\
\hline$x_{28}$ & $p_{28}$ & 0.667 & -1.000 & -1.000 & -1.000 & 2.333 \\
\hline & $r_{28}$ & -0.667 & 1.000 & 1.000 & 1.000 & -2.333 \\
\hline$x_{3}$ & & & & & & \\
\hline$x_{31}$ & $p_{31}$ & -0.194 & 0.145 & 0.110 & -0.206 & 0.145 \\
\hline & $r_{31}$ & 0.194 & -0.145 & -0.110 & 0.206 & -0.145 \\
\hline$x_{32}$ & $p_{32}$ & 0.588 & -0.628 & -0.081 & 0.750 & -0.628 \\
\hline & $r_{32}$ & -0.588 & 0.628 & 0.081 & -0.750 & 0.628 \\
\hline$x_{33}$ & $p_{33}$ & -0.547 & 0.565 & 0.126 & -0.708 & 0.565 \\
\hline & $r_{33}$ & 0.547 & -0.565 & -0.126 & 0.708 & -0.565 \\
\hline$x_{34}$ & $p_{34}$ & -0.818 & 0.562 & 0.435 & -0.741 & 0.562 \\
\hline & $r_{34}$ & 0.818 & -0.562 & -0.435 & 0.741 & -0.562 \\
\hline
\end{tabular}

Sum of positive and negative distances from the average solution

\begin{tabular}{|c|c|c|c|c|c|}
\hline$S_{i p}$ & 0.0817 & -0.3040 & 0.4101 & -0.2914 & 0.1037 \\
\hline$S_{i r}$ & -0.0405 & 0.2766 & -0.4239 & 0.3091 & -0.1213 \\
\hline
\end{tabular}

Step 8. Calculate the multi-criteria utility function values for all $m$ alternatives as follows:

$$
U_{i}=\frac{1}{2}\left(P_{i}+R_{i}\right)
$$

Step 9. Rank the alternatives in the decreasing order of multi-criteria utility function values $U_{i}$ The alternative with the highest $U_{i}$ is the best choice among the candidate alternatives. The alternatives can be arranged in the priority order according to this ranking (Table 5).
Table 5. Normalised positive and negative distances, the values of the calculated multi-criteria utility function values and final ranking of the alternatives

\begin{tabular}{llllll}
\hline \multicolumn{6}{l}{ Alternatives } \\
\cline { 2 - 6 } & $A_{1}$ & $A_{2}$ & $A_{3}$ & $A_{4}$ & $A_{5}$ \\
\hline$P_{i}$ & 0.199 & -0.741 & 1.000 & -0.711 & 0.253 \\
$R_{i}$ & 1.131 & 0.105 & 2.372 & 0.000 & 1.393 \\
$U_{i}$ & 0.665 & -0.318 & 1.686 & -0.355 & 0.823 \\
$\operatorname{Rank} A_{i}$ & 3 & 5 & 1 & 4 & 2 \\
\hline
\end{tabular}

Based on the calculations and taking into account the determined values of the criteria evaluating cultural heritage items, the order of heritage building renovation projects' implementation is as follows: $A_{3}>A_{5}>A_{1}>A_{4}>A_{2}$. The calculations have shown, that based on the considered criteria of problem evaluation, the priority should be given to the renovation works of the roof of the Assumption of the Blessed Virgin Mary Church in Raseiniai, and the largest investment should be made in this project, which would allow for reducing the time of project implementation.

\section{CONCLUSIONS}

Preservation of cultural heritage items is one of the strategic aims of national security policy. The items for renovation should be objectively and carefully selected. A hybrid multi-criteria evaluation model has been created for solving the problems associated with the strategic management of these items. A set of the criteria for evaluating the projects, concerning the renovation of cultural heritage items have been defined. These criteria include economic, historical-cultural and social issues. The economic criteria are as follows: the total project cost (thousand EUR) and the time of project implementation (months). Historical-cultural criteria (describing valuable qualities) are as follows: the nature of valuable qualities, architectural values, the value of architectural details, layout peculiarities, facade value, the value of structures, the peculiar features of finishing and the ground surface. Social criteria (according to particular districts) are as follows: the unemployment level, criminality, the average population and the conditions for tourism. Sub-criteria - time of project implementation - account for about $70 \%$ of the total assessment, which suggests that other sub-criteria have only a very minor role in the result.

The model for problem solution based on using multi-criteria evaluation methods AHP and EDAS. Taking into account the calculations made and the evaluation criteria used in the research, the first 
place (the priority) given to the renovation works of the roof of the Raseiniai Church, and the largest investment should be made in this project, which would allow for considerable reduction of the time of project implementation.

\section{REFERENCES}

Ashworth, G. J. 2010. Conservation designation and the revaluation of property: the risk of heritage innovation, International Journal of Heritage Studies 8(1): 9-23. http://dx.doi.org/10.1080/13527250220119901

Bielinskas,V.; Burinskienè, M.; Palevičius, V. 2015. Assessment of neglected areas in Vilnius city using MCDM and COPRAS methods, Procedia Engineering 122: 29-38.

http://dx.doi.org/10.1016/j.proeng.2015.10.004

Clark, K.; Maeer, G. 2008. The cultural value of heritage: evidence from the Heritage Lottery Fund, Cultural Trends 17(1): 23-56.

http://dx.doi.org/10.1080/09548960801920302

Dutta, M.; Husain, Z. 2009. An application of multicriteria decision making to built heritage. The case of Calcutta, Journal of Cultural Heritage 10(2): 237243. http://dx.doi.org/10.1016/j.culher.2008.09.007

Ferretti, V.; Bottero, M.; Mondini, G. 2014. Decision making and cultural heritage: an application of the Multi-Attribute Value Theory for the reuse of historical buildings, Journal of Cultural Heritage 15(6): 644-655.

http://dx.doi.org/10.1016/j.culher.2013.12.007

Filip, F. G.; Suduc, A.-M.; Bîzoi, M. 2014. DSS in numbers, Technological and Economic Development of Economy 20(1): 154-164. http://dx.doi.org/10.3846/20294913.2014.890139

Ghorabaee, M. K.; Zavadskas, E. K.; Amiri, M.; Turskis, Z. 2016. Extended EDAS method for fuzzy multicriteria decision-making: an application to supplier selection, International Journal of Computers Communications \& Control 11(3): 358-371.

Ghorabaee, M. K.; Zavadskas, E. K.; Olfat, L.; Turskis, Z. 2015. Multi-criteria inventory classification using a new method of Evaluation Based on Distance from Average Solution (EDAS), Informatica 26(3): 435451. http://dx.doi.org/10.15388/Informatica.2015.57

Jureniene, V.; Radzevicius, M. 2014. Models of cultural heritage management, Transformations in Business \& Economics 13(2): 236-256.

Ksiazek, M. V.; Nowak, P. O.; Kivrak, S.; Roslon, J. H.; Ustinovichius, L. 2015. Computer-aided decisionmaking in construction project development, Journal of Civil Engineering and Management 21(2): 248259. http://dx.doi.org/10.3846/13923730.2014.996250

Kultūros paveldo departamentas prie Kultūros ministerijos [Department of Culture Heritage under the Ministry of Culture]. 2016a. Bobriškio sentikiu bažnyčia [online]. Real Heritage Search. Available at: http://kvr.kpd.lt/\#/static-heritage-search.

Kultūros paveldo departamentas prie Kultūros ministerijos [Department of Culture Heritage under the Ministry of Culture]. 2016b. Vilniaus sinagoga [on- line]. Real Heritage Search. Available at: http://kvr. kpd.lt/\#/static-heritage-search.

Kultūros paveldo departamentas prie Kultūros ministerijos [Department of Culture Heritage under the Ministry of Culture]. 2016c. Raseiniu Svč. Mergeles Marijos Ėmimo $\dot{k}$ dangu bažnyčia [online]. Real Heritage Search. Available at: http://kvr.kpd.lt/\#/staticheritage-search.

Kultūros paveldo departamentas prie Kultūros ministerijos [Department of Culture Heritage under the Ministry of Culture]. 2016d. Zypliu dvaro sodybos amatininku namas [online]. Real Heritage Search. Available at: http://kvr.kpd.lt/\#/static-heritagesearch.

Kultūros paveldo departamentas prie Kultūros ministerijos [Department of Culture Heritage under the Ministry of Culture]. 2016e. Šv. Stepono bažnyčia [online]. Real Heritage Search. Available at: http:// kvr.kpd.lt/\#/static-heritage-search.

Kutut, V.; Zavadskas, E. K.; Lazauskas, M. 2013. Assessment of priority options for preservation of historic city centre buildings using MCDM (ARAS), Procedia Engineering 57: 657-661.

http://dx.doi.org/10.1016/j.proeng.2013.04.083

Kutut, V.; Zavadskas, E. K.; Lazauskas, M. 2014. Assessment of priority for preservation of historic buildings using model based on ARAS and AHP methods, Archives of Civil and Mechanic Engineering 14(2): 287294. http://dx.doi.org/10.1016/j.acme.2013.10.007

Lazauskas, M.; Kutut, V.; Zavadskas, E. K. 2015. Multicriteria assessment of unfinished construction projects, Gradevinar 67(4): 319-328.

Miller, G. A. 1956. The magical number seven, plus or minus two: some limits in our capacity for processing information, Psychological Review 63(2): 81-97. http://dx.doi.org/10.1037/h0043158

Morselli, A. 2015. The decision-making process between convention and cognition, Economics \& Sociology 8(1): 205-221. http://dx.doi.org/10.14254/2071-789X.2015/8-1/16

Pankhurst, C.; Harris, A. 2013. Conservation and innovation - the challenge of „Eco“ renovation in heritage buildings, Journal of Architectural Conservation 19(1): 18-34. http://dx.doi.org/10.1080/13556207.2013.787017

Peldschus, F.; Zavadskas, E. K.; Turskis, Z.; Tamosaitiene, J. 2010. Sustainable assessment of construction site by applying Game Theory, Inzinerine Ekonomika-Engineering Economics 21(3): 223-237.

Pourahmad, A.; Hosseini, A.; Banaitis, A.; Nasiri, H.; Banaitiene, N.; Tzeng, G. H. 2015. Combination of Fuzzy-AHP and Dematel-ANP with GIS in a new hybrid MCDM model used for the selection of the best space for leisure in a blighted urban site, Technological and Economic Development of Economy 21(5): 773-796.

http://dx.doi.org/10.3846/20294913.2015.1056279

Republic of Lithuania Law on Protection of Immovable Cultural Heritage. 2004. Lietuvos Respublikos Seimas, Valstybès žinios Nr. 153-5571.

Ruzgys, A.; Volvaciovas, R.; Ignatavicius, C.; Turskis, Z. 2014. Integrated evaluation of external wall insula- 
tion in residential buildings using SWARA-TODIM MCDM method, Journal of Civil Engineering and Management 20(1): 103-110.

http://dx.doi.org/10.3846/13923730.2013.843585

Saaty, T.L. 1980. The Analytic Hierarchy Process. New York: McGraw-Hill.

Saparauskas, J.; Zavadskas, E. K.; Turskis, Z. 2011. Selection of facade's alternatives of commercial and public buildings based on multiple criteria, International Journal of Strategic Property Management 15(2): 189-203.

http://dx.doi.org/10.3846/1648715X.2011.586532

Siozinyte, E.; Antucheviciene, J.; Kutut, V. 2014. Upgrading the old vernacular building to contemporary norms: multiple criteria approach, Journal of Civil Engineering and Management 20(2): 291-298. http://dx.doi.org/10.3846/13923730.2014.904814

Sivilevicius, H.; Zavadskas, E. K.; Turskis, Z. 2008. Quality attributes and complex assessment methodology of the asphalt mixing plant, Baltic Journal of Road and Bridge Engineering 3(3): 161-166. http://dx.doi.org/10.3846/1822-427X.2008.3.161-166

Stankevicius, V.; Karbauskaite, J.; Burlingis, A.; Sadauskiene, J.; Morkvenas, R. 2014. Expanding the possibilities of building modernization: case study of Lithuania, Journal of Civil Engineering and Management 20(6): 819-828. http://dx.doi.org/10.3846/13923730.2014.929599

Tupėnaitè, L.; Zavadskas, E. K.; Kaklauskas, A.; Turskis, Z.; Seniut, M. 2010. Multiple criteria assessment of alternatives for built and human environment renovation, Journal of Civil Engineering and Management 16(2): 257-266. http://dx.doi.org/10.3846/jcem.2010.30

Turskis, Z.; Zavadskas, E. K.; Antucheviciene, J.; Kosareva, N. 2015. A hybrid model based on fuzzy AHP and fuzzy WASPAS for construction site selection, International Journal of Computers Communications \& Control 10(6): 873-888.

Turskis, Z.; Zavadskas, E. K.; Kutut, V. 2013. A model based on ARAS-G and AHP methods for multiple criteria prioritizing of heritage value, International
Journal of Information Technology \& Decision Making 12(1): 45-73.

http://dx.doi.org/10.1142/S021962201350003X

Turskis, Z.; Zavadskas, E. K.; Peldschus, F. 2009. Multi-criteria optimization system for decision making in construction design and management, Inzinerine Ekonomika-Engineering Economics 61(1): 7-17.

Urbaniec, M. 2015. Towards sustainable development through eco-innovations: drivers and barriers in Poland, Economics \& Sociology 8(4): 179-190. http://dx.doi.org/10.14254/2071-789X.2015/8-4/13

Vodopivec, B.; Žarnic, R.; Tamošaitienè, J.; Lazauskas, M.; Šelih, J. 2014. Renovation priority ranking by multi-criteria assessment of architectural heritage: the case of castles, International Journal of Strategic Property Management 18(1): 88-100. http://dx.doi.org/10.3846/1648715X.2014.889771

Zagorskas, J.; Zavadskas, E. K.; Turskis, Z.; Burinskiene, M.; Blumberga, A.; Blumberga, D. 2014. Thermal insulation alternatives of historic brick buildings in Baltic Sea Region, Energy and Buildings 78: 35-42.

http://dx.doi.org/10.1016/j.enbuild.2014.04.010

Zavadskas, E. K.; Kaklauskas, A.; Turskis, Z.; Kalibatas, D. 2009b. An approach to multi-attribute assessment of indoor environment before and after refurbishment of dwellings, Journal of Environmental Engineering and Landscape Management 17(1): 5-11. http://dx.doi.org/10.3846/1648-6897.2009.17.5-11

Zavadskas, E. K.; Kaklauskas, A.; Turskis, Z.; Tamosaitiene, J. 2009a. Multi-attribute decision-making model by applying grey numbers, Informatica 20(2): 305-320.

Zavadskas, E. K.; Turskis, Z.; Bagocius, V. 2015. Multicriteria selection of a deep-water port in the Eastern Baltic Sea, Applied Soft Computing 26: 180-192. http://dx.doi.org/10.1016/j.asoc.2014.09.019

Zavadskas, E. K.; Turskis, Z.; Kildiene, S. 2014. State of art surveys of overviews on MCDM/MADM methods, Technological and Economic Development of Economy 20(1): 165-179.

http://dx.doi.org/10.3846/20294913.2014.892037 